\title{
КРИПТОВАЛЮТНІ ВІДНОСИНИ В УКРАЇНІ: ЕКОНОМІКО-ПРАВОВИЙ АНАЛІЗ
}

\section{CRYPTOCURRENCY RELATIONS IN UKRAINE: ECONOMIC AND LEGAL ANALYSIS}

\author{
Ковтун Володимир Володимирович \\ бакалаврант, \\ Національний юридичний університет імені Ярослава Мудрого \\ ORCID: https://orcid.org/0000-0002-0660-1320 \\ Овсієнко Ольга Вікторівна \\ кандидатка економічних наук, доцентка, \\ Національний юридичний університет імені Ярослава Мудрого \\ ORCID: https://orcid.org/0000-0002-6467-9396
}

\author{
Kovtun Volodymyr, Ovsiienko Olha \\ Yaroslav the Wise National Law University
}

\begin{abstract}
У статті розглядаються передумови фрормування та розвитку криптовалютних відносин, стан їх правового регулювання в Україні. Доведено, що правове регулювання криптовалютних відносин в Україні недостатнє, що має негативні економічні наслідки у вигляді шахрайства, недоотримання державним бюджетом коштів. Обґрунтовано шляхи удосконалення нормативно-правового регулювання криптовалютних відносин, а саме: упорядкування термінологічної бази; визначення напрямів роботи з криптовлютними активами; встановлення дозволу юридичним особам на роботу з криптовалютою; регламентація оподаткування криптовалютних операцій. Визначено позитивні соціально-економічні наслідки унормування криптовалютного обігу - введення криптовалют у господарський обіг, запобігання економічному шахрайству, збільшення надходжень до державного бюджету.

Ключові слова: криптовалюта, криптовалютні відносини, цифрова валюта, блокчейн, правове регулювання криптовалютних відносин в Україні.
\end{abstract}

В статье рассматриваются предпосылки фрормирования и развития криптовалютных отношений, их правового регулирования в Украине. Доказано, что правовое регулирование криптовалютных отношений в Украине недостаточно, следствием чего являются негативные экономические последствия в виде мошенничества, недополучение государственным бюджетом средств. Обоснованы пути усовершенствования нормативно-правового регулирования криптовалютных отношений, а именно: составление терминологической базы; определение направлений работы с криптовлютными активами; унормирование выдачи разрешений юридическим лицам работать с криптовалютой; регламентация налогообложения криптовалютных операций. Определены положительные социально-экономические последствия унормирования криптовалютного оборота - введение криптовалют в хозяйственный оборот, предотвращение экономического мошенничества, увеличение поступлений в государственный бюджет.

Ключевые слова: криптовалюта, криптовалютные отношения, цифровая валюта, блокчейн, правовое регулирование криптовалютных отношений в Украине.

The article is devoted to the consideration of the key prerequisites for the formation and development of cryptocurrency, the principles and methods of its creation, its economic nature, the state of legal regulation of cryptocurrency relations in Ukraine. The relevance of considering this issue arises, since cryptocurrency is becoming a widespread phenomenon in our country and the world as a whole, which is caused by scientific and technical progress, which has become a dotic phenomenon in all spheres of human life. Ways to improve the legislative regulation of cryptocurrency relations are proposed, since in our country it is imperfect, in particular in civil law (the introduction of cryptocurrency as an object of civil circulation), commercial law (the ability to provide legal entities with the necessary licenses to work with cryptocurrency in the process of commercial and other activities), criminal law (creation of prerequisites for the introduction of cryptocurrency as an object of special confiscation, and so on), tax law (the problem of taxation of cryptocurrency transactions and the establishment of the required amount of tax duty on them), improvement of the terminological base, a pattern is indicated in determining the directions of work 
with cryptocurrency assets, defined their potential economic consequences for the economy of our state. Conclusions are made about the positive features of cryptocurrency, the risks of this economic phenomenon are identified, the possibility of leveling the harmful consequences of risks by regulating these processes at the legislative level is considered. Analyzed the work of famous scientists working with finance, financial law in the field of the essence of cryptocurrency and related processes, their economic and legal nature. The approaches of various scientists regarding the settlement of cryptocurrency relations in our country were investigated. Conclusions are made about the state of cryptocurrency relations in the country based on statistical data. Through the prism of history, the evolution of the development of legislative thought in Ukraine regarding the normalization of cryptocurrency relations was considered, errors were indicated during the development of these bills. The international experience of different countries in relation to cryptocurrency and its introduction into financial circulation, establishing control over these operations has been investigated.

Keywords: cryptocurrency, cryptocurrency relations, digital currency, blockchain, legal regulation of cryptocurrency relations in Ukraine

Постановка проблеми. XXI століття період кардинальних змін в усіх сорерах економіки. Так, у грошово-кредитній ссрері поступового розповсюдження набуває криптовалюта. За даними Р. Родіна, щоденний обіг криптовалюти у світі становить близька чвертітрильйону доларів США [1]. Україна також бере активну участь в операціях з криптовалютою. У 2021 р. наша країна увійшла в ТОП-5 Рейтингу впровадження криптовалюти (The 2021 Global Crypto Adoption Index) та посіла четверте місце за обсягом операцій з нею [2]. Проте правове регулювання цих відносин поки що недостатнє, зокрема не створено чіткого понятійного апарату в цій сорері, не унормовано процедури використання криптовалюти як платіжного засобу, не встановлені правила оподаткування операцій з криптовалютою тощо. Через це суб'єкти криптовалютних відносин стикаються з численними ризиками - шахрайством, неможливістю здійснювати трансакції у правовому полі. Законодавча база криптовалютного обігу потребує удосконалення, що зумовлює необхідність системного економіко-правового аналізу крипто валютних відносин.

Аналіз останніх досліджень і публікацій. Криптовалюта $є$ новим поняттям для економічної науки та права. Дослідження цього феномену розпочалися не так давно. У роботах А. Генкіна та А. Михеєва [3], І. Дороніна [4], Л. Островерх та В. Нарогана [5], В. Усоського [6] та інших визначається роль криптовалюти у платіжній системі країни. Г. Гілмен (G. Hileman) та M. Рочс (M. Rauchs) [7], А. Кудь, М. Кучерявенко, Є. Смичок [8], Р. Фарел (R. Farell) [9], К. Ярова [10] аналізують механізми криптовалютного обігу. Значна увага вітчизняних науковців приділяється правовому регулюванню криптовалют в Україні (Д. Кобильник, А. Бурчак [11], В. Радінська [12], Р. Родін [1], М. Шаренко [13] та інші).

Виділення невирішених раніше частин загальної проблеми. Попри активізацію наукового пошуку у сорері регулювання криптовалютних відносин, дискусійним питанням $\epsilon$ економіко-правовий зміст понять «криптовалюта» «блокчейн», «майнинг», а також деяких криптовалютних процесів. Недостатньо дослідженими залишаються соціальноекономічні наслідки різних варіантів унормування криптовалютних відносин.

Формулювання цілей статті. Метою дослідження є уточнення змісту криптовалютних відносин, обґрунтування напрямів удосконалення їх правового регулювання, а також визначення соціально-економічних наслідків конкретних способів унормування криптовалютних відносин.

Виклад основного матеріалу дослідження. Криптовалюту часто вважають різновидом цифрових валют $[1 ; 2 ; 4$, с. 86; 6, с. 54; 12, с. 175-176]. Її можна визначити як різновид цифрової валюти, емісія та облік якої виконується децентралізованою платіжною системою повністю в автоматичному режимі (без можливості внутрішнього або зовнішнього адміністрування) [5, с. 25-26; 6, с. 54-55].

Емісія та облік криптовалюти здійснюються на основі криптограсрічних методів, наприклад, асиметричному шифруванні та методі захисту Proof-of-Work. Для того, щоб створити таку «монету», необхідно встановити спеціальне програмне забезпечення. Це програмне забезпечення певний час генерує («майнить») унікальний ключ, складність якого залежить від величини навантаження на мережу та загальної потужності майнерів. Саме складність добування криптовалюти забезпечує ії цінність. Результат генерації - криптографрічна послідовність, вона і $€$ кінцевою валютою. Феноменальність криптовалюти полягає в іiї протоколі, який автоматизує стимули до вигідної системі поведінки. Звернемо увагу на відмінності між фріатною валютою та криптовалютою. Фіатна валюта - платіжний засіб, цінність якого штучно встановлюється державою. 
що важливо, цінність цієї валюти не забезпечується прив'язкою до конкретних активів. Якщо раніше, наприклад, цінність валюти певної країни визначалася ії золотим запасом, то тепер єдиний гарант вартості - авторитет уряду [4, с. 86; 5, с. 27-28; 6, с. 54-55]. Порівняно 3 фріатною валютою, криптовалюта не $€$ платіжною вимогою до емітента. Фіатна валюта $€$ зобов'язанням центрального банку або комерційних банків [9, с. 9-10].

Некоректним, на нашу думку, є ототожнення криптовалюти 3 електронними грошима, адже ці поняття діаметрально протилежні в дискурсі валютного ринку. Електронні гроші - це різновид грошей чи фрінансових зобов'язань, обмін та взаєморозрахунки за якими проводяться за допомогою індрормаційних технологій (наприклад, гроші, які перебувають на банківських рахунках). Розповсюдження електронних грошей навіть уможливило зникнення та нівелювало необхідність «живих» банківських відділень. Так, в додатку Universal bank для онлайн-банкінгу «monobank», всі операції здійснюються за допомогою додатку в смартороні, що є надзвичайно зручним. До речі, нещодавно керівництво Universal bank заявило, що в «monobank» буде можливо створювати електронні гаманці для зберігання криптовалюти та купувати ії через цей додаток. Слід зауважити, що сума грошей, яка перебуває в електронній формі, еквівалентна кількості паперових грошей, які знаходяться в банку, чого не можна сказати про криптовалюту.

До основних властивостей криптовалюти можна віднести такі:

- відсутність центрального органу управління. Криптовалюта, на відміну від фріатної валюти, не регулюється центральною грошово-кредитною установою. Контроль за процесами використання криптовалюти базується на тому, що учасники тримають ідентичні повні бази даних балансів усіх гаманців, і змінити базу можливо лише за умови повного консенсусу системи. Саме такий механізм збільшує довіру до цього виду віртуальної валюти, оскільки майже унеможливлює процес підробки криптовалюти або скасування відповідного коду;

- у криптовалютах немає примусового повернення платежів, оскільки немає адміністрування, кошти не можуть бути примусово заморожені або вилучені без доступу до приватного ключа власника. Однак $€$ можливості укладання угод за участю посередника, коли для завершення або скасування угоди потрібна згода всіх трьох або довільних двох сторін. Учасники угоди можуть добровільно тимчасово взаємно блокувати свої кошти як заставу. Точніше, криптовалюта буде перерахована на спеціальний рахунок, для розпорядження яким потрібна згода всіх або кількох сторін. При цьому будь-яка сторона самостійно неспроможна виконати будь-яку операцію;

- наявність верхньої межі загального обсягу емісії. Проте існують певні види криптовалюти, у яких ця верхня межа відсутня, і можлива як емісія за рахунок накопичень, так і демісія шляхом обов'язкового знищення невеликої фріксованої суми в кожній транзакції.

Захищеність криптовалют зумовлена технологією блокчейн, яка забезпечує стабільність криптовалюти. У монографрії А. Кудя, М. Кучерявенка та $Є$. Смичка «Цифрові активи та їх правове регулювання» охарактеризовано головні переваги блокчейну, серед яких [8, с. 11]:

1. Блокчейн $€$ розподіленим реєстром i буде функціонувати до останнього активного мережевого вузла.

2. Доступ до історії транзакцій блокчейну мають всі учасники мережі, а повного контролю над ним немає ніхто.

3. У мережі блокчейн відсутня ієрархія, тобто серед безлічі мережевих вузлів нема головного.

4. За своєю природою блокчейн здатен поєднати відкритість та захищенність даних користувачів. Високий ступінь надійності забезпечується за допомогою прогресивних методів шифрування.

5. Дані в мережі блокчейн неможливо видалити або замінити, бо вони підтверджуються безліччю мережевих вузлів.

6. Технологія блокчейн забезпечує абсолютну прозорість, оскільки доступ до інформації про всі операції відкритий і кожен може перевірити її вірогідність.

7. Мережа блокчейн $€$ «довірчою» системою, бо транзакції здійснюються прямо між іiі учасниками, автоматично перевіряються та підтверджуються безліччю вузлів мережі й не потребують посередників, що повністю виключає недовіру до однієї організації-посередника. Як наслідок, це приводить до значного зменшення вартості транзакції за рахунок скорочення комісійних витрат, а також до збільшення швидкості транзакцій внаслідок скорочення витрат часу.

Водночас особливості криптовалютного обігу зумовлюють численні ризики, а саме:

- можливість шахрайських дій. Один 3 найуспішніших та найбагатших інвесторів у світі 
Воррен Бафрфет висловив таку думку про криптовалюти: «Дивіться, ось я відриваю ґудзик, і ми використовуємо його, як невеликий токен. Я пропоную вам його за \$1000 і сподіваюся, що під кінець дня він виросте до \$2000. Люди, звичайно, будуть створювати їх (такі токени) у величезних кількостях. Це інструмент для азартних ігор, з ним пов'язано багато шахрайства, і люди втрачали великі гроші» [14];

- складність конвертації у паперову валюту, оскільки цей механізм є витратним та недостатньо законодавчо врегульованим;

- нестабільність курсу криптовалюти по відношенню до звичайної валюти. Це можна спостерігати на прикладі Bitcoin. Курс цього виду криптовалюти є нестабільним, мінливим. Він навіть змінюється від постів в соціальних мережах (від постів Ілона Маска курс як стрімко зростав, так і починав падати), що не можна сказати про фріатну валюту (долари, євро), курс яких все ж можна спрогнозувати 3 певною похибкою.

В Україні криптовалютні відносини активно розвиваються. Наша країна посідає 4-те місце за криптовалютною активністю - інтегральним показником, розрахованим Chainalysis для 154 країн світу (табл. 1). Цей показник визначається на основі таких даних: загальної кількості криптовалют, отриманих країною; активності непрофресійних індивідуальних користувачів криптовалюти (обсяг криптовалютних операцій у порівнянні 3 багатством середньої людини в країні); обсягу біржової торгівлі криптовалютою.

Таблиця 1

\begin{tabular}{|l|c|c|}
\multicolumn{1}{|c|}{ Країна } & $\begin{array}{c}\text { Індексний } \\
\text { бал }\end{array}$ & $\begin{array}{c}\text { Загальний } \\
\text { рейтинговий } \\
\text { індекс }\end{array}$ \\
\hline В'єтнам & 1 & 1 \\
\hline Індія & 0,37 & 2 \\
\hline Пакистан & 0,36 & 3 \\
\hline Україна & 0,29 & 4 \\
\hline Кенія & 0,28 & 5 \\
\hline Нігерія & 0,26 & 6 \\
\hline Венесуела & 0,25 & 7 \\
\hline США & 0,22 & 8 \\
\hline Того & 0,19 & 9 \\
\hline Аргентина & 0,19 & 10 \\
\hline
\end{tabular}

Джерело: складено авторами на основі [2]

Необхідність правового регулювання крипто валютних відносин визнається у багатьох дослідженнях [8; 10, с. 1119; 11, с. 24; 13].
По-перше, право є фрундаментальним каркасом цивілізованого розвитку криптовалютних відносин. По-друге, правове регулювання активно сприяє створенню та забезпеченню гарантій безпечного використання криптовалюти (держава не може захистити права власників без належної законодавчої бази). По-третє, оподаткування деяких криптовалютних операцій може значно поповнити державний бюджет.

В Україні були здійснені спроби правового регулювання криптовалютних відносин. Першою ініціативою був проєкт Закону України (далі 3У) «Про обіг криптовалюти в Україні». В ньому було визначено зміст основних понять у ссрері криптовалютних відносин, запропоновані механізми впровадження криптовалюти в обіг, однак законопроєкт було відхилено та відправлено на доопрацювання. Далі на розгляд Верховній Раді України було подано проєкт ЗУ «Про стимулювання ринку криптовалют та їх похідних в Україні». Він мав на меті регламентацію загальних засад фрункціонування та правового регулювання ринку криптовалюти та похідних, однак також не був ухвалений та відправлений на доопрацювання. Ще однією законодавчою ініціативою був проєкт ЗУ «Про внесення змін до Податкового кодексу України щодо оподаткування операцій з віртуальними активами в Україні». Термінологічна база проєкту заслуговує на увагу, оскільки було здійснено спробу хоча б частково заповнити прогалину в законодавстві. Разом з тим, мають місце окремі термінологічні неточності, а саме [1; 8, с. 140-142; 13, с. 50-54]:

- при визначенні поняття «віртуальний актив» майже ототожнюються несумісні поняття «криптовалюти» та токен-активів;

- визначення поняття «майнинг» не містить вказівки на мету та форму цієї діяльності;

- визначення поняття «реєстр» $є$ недостатньо конкретним та однозначним, що може призвести до хибного зіставлення з цим поняттям великої кількості об'єктів, які не мають до нього жодного відношення.

Серед інших законодавчих ініціатив, що безпосередньо пов'язані з регулюванням криптовалютних відносин, можна виділити ухвалений в другому читанні та в цілому проєкт ЗУ «Про платіжні послуги». Відповідно до ст. 3 законопроєкту грошові кошти існують в Україні у готівковій (формі грошових знаків) та безготівковій (фрормі записів на рахунках) фрормах. Грошові кошти включають також електронні гроші та цифрові гроші, які існують лише в безготівковій фрормі. Також цей законопроєкт впроваджує механізм отримання ліцензії від НБУ для 
випуску цифрових грошей. Однак законопроєкт не регулює в повному обсязі сам процес використання криптовалюти.

Проривом у сорері унормування криптовалютних відносин є прийнятий в другому читанні та в цілому проєкт ЗУ «Про віртуальні активи».

Він врегульовує:

- права та обов'язки учасників ринку віртуальних активів;

- послуги зі зберігання або адміністрування віртуальних активів або ключів віртуальних активів;

- послуги з обміну віртуальних активів;

- послуги з переказу віртуальних активів;

- фрінансові послуги, пов'язані з публічною пропозицією та/або продажем віртуальних активів.

Центральними органами влади, який формує і реалізує державну політику в ссрері обігу віртуальних активів, є Національний банк України та Національна комісія з цінних паперів та фрондового ринку. На них покладені завдання, зокрема, здійснення державного регулювання та контролю за обігом віртуальних активів на території України, забезпечення та здійснення контролю за виконанням, в межах компетенції, учасниками ринку віртуальних активів законодавства у сфрері запобігання та протидії легалізації (відмиванню) доходів, одержаних злочинним шляхом, фрінансуванню тероризму та фрінансуванню розповсюдження зброї масового знищення.

Законопроєкт визначає правовий статус та вимоги до постачальників послуг, пов'язаних з віртуальними активами, через проходження процедур державної реєстрації одного або декількох видів діяльності:

- зберігання або адміністрування віртуальних активів та ключів віртуальних активів;

- обмін віртуальних активів;

- переказ віртуальних активів;

- участь і надання фрінансових послуг, пов'язаних із пропозицією емітента та/або продажем віртуальних активів. Однак не прописана повноцінна процедура, за допомогою якої можна добувати криптовалюту.

На нашу думку, основними напрямами удосконалення нормативно-правового регулювання криптовалютних відносин мають стати такі:

1. Упорядкування термінологічної бази. Потрібно чітко встановити, що таке криптовалюта, які в неї ознаки тощо. Це необхідно зробити для уникнення колізій в регулюванні, адже без розуміння суті предмету регулювання, неможливо розбудувати повноцінну законодавчу базу. Також це унеможливить спекулятивні махінації, спрямовані на ухи- лення від оподаткування та відповідальності. Наприклад, у разі відсутності термінологічного визначення, буде набагато простіше в процесі судового розгляду уникнути відповідальності, доводячи, що діяння не пов'язані з криптовалютою. Оскільки суд не зможе без чіткого визначення криптовалюти надати кваліфрікацію діянням, то $€$ висока вірогідність виправдання обвинуваченого. Щоб розв'язати цю проблему, необхідно прийняти певний «загальний» закон, який буде чітко визначати понятійний апарат криптовалюти та похідних для неї термінів (блок-чейн, майнинг тощо), встановить основні риси криптовалютних відносин та вирішить інші загально-теоретичні проблеми. Мають бути законодавчо встановлені механізми майнингу криптовалюти, механізми отримання права власності на ці активи.

2. Внесення змін у Цивільний кодекс України (далі - ЦКУ). У ЦКУ потрібно вказати, що саме можна робити 3 криптовалютними активами. Суб'єкт правових відносин має розуміти, які у нього будуть можливості в разі декларування криптовалюти: чи можна буде передавати ії у спадок, дарувати, розраховуватися, відстоювати право на володіння в суді тощо. Тому, для початку, потрібно внести зміни до статті 177 ЦКУ, а саме, на нашу думку, викласти її в такій редакції: «Об'єктами цивільних прав $є$ речі, у тому числі гроші (в електронному та паперовому вигляді), віртуальні активи, цифрова валюта (криптовалюта та інші) та цінні папери, інше майно, майнові права, результати робіт, послуги, результати інтелектуальної, творчої діяльності, інформація, а також інші матеріальні і нематеріальні блага». Така зміна допоможе ввести криптовалюту в повноцінний обіг, зробити ії повноцінним об'єктом цивільних правовідносин.

3. Внесення змін до нормативно-правових актів у сорері господарського та банківського законодавства для встановлення дозволу юридичним особам на роботу з криптовалютою. На даний момент жодна фрірма, банк або інші організації не мають права працювати 3 криптовалютою. Зміни в цих галузях необхідні для уможливлення роботи з криптовалютою та визначення дозволених принципів, методів та способів регламентації криптовалютних операцій. Все це сприятиме зменшенню нелегальних доходів, які не проходять оподаткування, підвищить темпи розвитку ринку криптовалюти. Також фрізичні особи зможуть використовувати криптовалюту як платіжний засіб, а також зберігати її на банківських рахунках.

4. Регламентація оподаткування криптовалютних операцій. у Податковому кодексі 
України необхідно встановити розмір податку, методи оподаткування криптовалютних доходів та операцій. Необхідно запровадити прозорий механізм ліцензування діяльності 3 криптовалютою для юридичних осіб.

5. Встановлення кримінальної відповідальності за злочинні дії з криптовалютою (незаконний майнинг, шахрайські махінації тощо). Також потрібно визначити статус криптовалюти в кримінальному праві: визнати їі предметом спеціальної конфіскації, описати сореру застосування криптовалюти в корупційних злочинах та інші заходи.

Чи можна частково нівелювати ризики криптовалюти за допомогою права? Однозначно. Правове регулювання зменшує шахрайські ризики, у користувачів з'явиться можливість відстоювати свої права в сорері криптовалютних відносин. Якщо наша країна визнає криптовалюту на законодавчому рівні, це сприятиме стабілізації курсу по відношенню до фріатних валют, у подальшому спричинить розвиток конвертаційних механізмів.

Висновки. Можна стверджувати, що криптовалюта стає поширеним явищем в нашій країні та у світі загалом. В основі створення криптова- люти лежить механізм генерації коду, цінність криптовалюти визначається кількістю витраченої електроенергії та попиту на цю валюту. В Україні попит на криптовалюту невисокий, тому в нашій країни існує надлишок криптовалюти. Правове регулювання криптовалютних відносин в Україні недостатнє, що має негативні економічні наслідки у вигляді шахрайства, недоотримання державним бюджетом коштів. Основними напрямами удосконалення нормативно-правового регулювання криптовалютних відносин мають стати: упорядкування термінологічної бази; визначення напрямів роботи 3 криптовлютними активами; встановлення дозволу юридичним особам на роботу 3 криптовалютою; регламентація оподаткування криптовалютних операцій.

Враховуючи те, що завдяки унормуванню криптовалютних відносин їх спектр може суттєво розширитися, подальші дослідження у цій ссрері доцільно зосередити на пошуку оптимальних фоорм та способів інтеграції відповідних правових норм у чинну систему законодавства, а також на визначені соціальноекономічних наслідків нормативно-правового регулювання криптовалюти.

\section{СПИСОК ВИКОРИСТАНИХ ДЖЕРЕЛ:}

1. Родін Р. Чому Україна легалізує криптовалюту не з того кінця? URL: https://www.epravda.com.ua/rus/ columns/2021/01/26/670382/

2. The 2021 Global Crypto Adoption Index: Worldwide Adoption Jumps Over $880 \%$ With P2P Platforms Driving Cryptocurrency Usage in Emerging Markets. URL: https://blog.chainalysis.com/reports/2021-global-crypto-adoption-index

3. Генкин А.С., Михеев А.А. Блокчейн. Как работает и что ждет нас завтра : монограсрия. Москва : ООО «Альпина Паблишер», 2018. 281 с.

4. Доронін І.М. Криптовалюти: соціально-економічні фрактори, право та фрункції держави. Інформація $i$ право. 2017. № 3. C. 85-93. URL: http://ippi.org.ua/sites/default/files/11_5.pdf

5. Островерх Л.Л., Нароган В.В. Криптовалюта як повноцінний учасник платіжної системи країни: реальність чи ілюзія. Економіка. Фінанси. Право. 2019. № 7(2). С. 24-29. URL: http://nbuv.gov.ua/UJRN/ ecfipr_2019_7\%282\%29_7

6. Усоский В.Н. Криптовалюта как абстрактное обязательство и условие эмиссии банком кредитных денег. Часопис економічних реформ. 2018. № 4(32). C. 52-57. URL: http://nbuv.gov.ua/UJRN/Cher_2018_4_11

7. Hileman G., Rauchs M. Global cryptocurrency benchmarking study. Cambridge Centre for Alternative Finance, 2017. URL: https://www.crowdfundinsider.com/wp-content/uploads/2017/04/Global-Cryptocurrency-BenchmarkingStudy.pdf

8. Кудь А., Кучерявенко М., Смичок $Є$. Цифррові активи та їх правове регулювання у світлі розвитку технології блокчейн : монограсрія. Харків : Право, 2019. 216 с.

9. Farell R. An Analysis of the Cryptocurrency Industry. Wharton Research Scholars. 2015. № 5. URL: https://repository.upenn.edu/cgi/viewcontent.cgi?article=1133\&context=wharton_research_scholars

10. Ярова К.О. Криптовалюта: визначення правового статусу в Україні. Молодий вчений. 2017. № 10. C. 1117-1120. URL: http://nbuv.gov.ua/UJRN/molv_2017_10_253

11. Кобильник Д.А., Бурчак А.Ю. Криптовалюта як об'єкт податкового права: практичне застосування та правове регулювання. Право та інновації. 2020. № 2. C. 24-30. DOI: https://doi.org/10.37772/2518-1718-2020-2(30)-3

12. Радінська В.О. Оподаткування операцій з криптовалютами: досвід Європейського Союзу. Вороновські читання. Співвідношення матеріального та процесуального в регулюванні фрінансових відносин : матеріали міжнар. наук.-практ. конф. (Чернівці, 4-5 жовт. 2017 р.). Чернівці, 2017. С. 175-179. 
13. Шаренко М.С. Правове регулювання криптовалют в Україні. Вороновські читання. Співвідношення матеріального та процесуального в регулюванні фрінансових відносин : матеріали міжнар. наук.-практ. конср. (Чернівці, 4-5 жовт. 2017 р.). Чернівці, 2017. С. 247-248.

14. Кузюк Д. Уоррен Бафрфет: Биткоин ничем не отличается от морской ракушки. Портал 2Bitcoins.ru. 5 травня 2019 р. URL: https://2bitcoins.ru/bitkoin-morskaja-rakushka/

15. Криптовалюта в Україні: технологія, ринок, регулювання. Проєкт USAID «Tрансформація фрінансового сектору». Київ, 2018. 93 с. URL: https://zakon.help/files/article/9634/Cryptocurrency_Paper_Sept2018_ua.pdf

\section{REFERENCES:}

1. Rodin, R. Chomu Ukraina legalisue cryptovalyutu ne $z$ togo kintsya? [Why is Ukraine legalizing cryptocurrency from the wrong end?]. Retrieved from: https://www.epravda.com.ua/rus/columns/2021/01/26/670382/

2. The 2021 Global Crypto Adoption Index: Worldwide Adoption Jumps Over $880 \%$ With P2P Platforms Driving Cryptocurrency Usage in Emerging Markets (2021). Retrieved from: https://blog.chainalysis.com/reports/2021global-crypto-adoption-index

3. Genkin, A. S., \& Mikheev A. A. (2018) Blockchain. Kak rabotaet i chto zhdet nas zavtra [Blockchain. How it works and what awaits us tomorrow]. Moscow: Alpina Publisher. (in Russian)

4. Doronin, I. M. (2017) Kriptovalyuty: socialno-ekonomichni faktory, pravo ta funkciyi derzhavi. Informaciya i pravo [Cryptocurrencies: socio-economic factors, law and functions of the state]. Informaciya i pravo - Information and law, 3, 85-93. Retrieved from: http://ippi.org.ua/sites/default/files/11_5.pdf (in Ukrainian)

5. Ostroverh, L. L., \& Narogan, V. V. (2019) Kriptovalyuta yak povnocinnij uchasnik platizhnoyi sistemi krayini: realnist chi ilyuziya [Cryptocurrency as a full participant in the country's payment system: reality or illusion]. Ekonomika. Finansi. Pravo - Economy. Finances. Law, 7(2), 24-29. Retrieved from: http://nbuv.gov.ua/UJRN/ ecfipr_2019_7\%282\%29_7 (in Ukrainian)

6. Usoskij, V. N. (2018) Kriptovalyuta kak abstraktnoe obyazatelstvo i uslovie emissii bankom kreditnyh deneg [Cryptocurrency as an abstract obligation and a condition for a bank to issue credit money]. Chasopis ekonomichnih reform - Journal of Economic Reforms, 4(32), 52-57. Retrieved from: http://nbuv.gov.ua/UJRN/Cher_2018_4_11 (in Russian)

7. Hileman, G., \& Rauchs, M. (2017) Global cryptocurrency benchmarking study. Cambridge Centre for Alternative Finance. Retrieved from: https://www.crowdfundinsider.com/wp-content/uploads/2017/04/Global-Cryptocurrency-Benchmarking-Study.pdf

8. Kud, A., Kucheryavenko, M., \& Smichok, Ye. (2019) Cifrovi aktivi ta yih pravove regulyuvannya u svitli rozvitku tehnologiyi blokchejn [Digital assets and their legal regulation in the light of the development of blockchain technology]. Kharkiv: Pravo. (in Ukrainian)

9. Farell, R. (2015) An Analysis of the Cryptocurrency Industry. Wharton Research Scholars, 5. Retrieved from: https://repository.upenn.edu/cgi/viewcontent.cgi?article=1133\&context=wharton_research_scholars

10. Yarova, K. O. (2017) Kriptovalyuta: viznachennya pravovogo statusu v Ukrayini [Cryptocurrency: determining the legal status in Ukraine]. Molodij vchenij - Young scientist, 10, 1117-1120. Retrieved from: http://nbuv.gov.ual UJRN/molv_2017_10_253 (in Ukrainian)

11. Kobilnik, D. A., \& Burchak, A. Yu. (2020) Kriptovalyuta yak ob'yekt podatkovogo prava: praktichne zastosuvannya ta pravove regulyuvannya [Cryptocurrency as an object of tax law: practical application and legal regulation]. Pravo ta innovaciyi - Law and innovation, 2, 24-30. DOI: https://doi.org/10.37772/2518-1718-2020-2(30)-3 (in Ukrainian)

12. Radinska, V. O. (2017) Opodatkuvannya operacij z kriptovalyutami: dosvid Yevropejskogo Soyuzu [Taxation of cryptocurrency transactions: the experience of the European Union]. Proceedings from Voronovski chitannya. Spivvidnoshennya materialnogo ta procesualnogo $v$ regulyuvanni finansovih vidnosin: materialy mizhnar. nauk.-prakt. konf. - Voronov readings. The ratio of material and procedural in the regulation of financial relations (Chernivtsi, October 4-5th, 2017) (pp. 175-179). Chernivtsi. (in Ukrainian)

13. Sharenko, M. S. (2017) Pravove regulyuvannya kriptovalyut v Ukrayini [Legal regulation of cryptocurrencies in Ukraine]. Proceedings from Voronovski chitannya. Spivvidnoshennya materialnogo ta procesualnogo $v$ regulyuvanni finansovih vidnosin: materiali mizhnar - Voronov readings. The ratio of material and procedural in the regulation of financial relations (Chernivtsi, October 4-5th, 2017) (pp. 247-248). Chernivtsi. (in Ukrainian)

14. Kuzyuk, D. (2019) Uorren Baffet: Bitkoin nichem ne otlichaetsya ot morskoj rakushki [Warren Buffett: Bitcoin is no different from a seashell]. Portal 2Bitcoins.ru. Retrieved from: https://2bitcoins.ru/bitkoin-morskaja-rakushka/ (in Russian)

15. Kriptovalyuta v Ukrayini: tehnologiya, rinok, regulyuvannya (2018) Proyekt USAID «Transformaciya finansovogo sektoru» [Cryptocurrency in Ukraine: technology, market, regulation. USAID Financial Sector Transformation Project]. Retrieved from: https://zakon.help/files/article/9634/Cryptocurrency_Paper_Sept2018_ua.pdf (in Ukrainian) 